\title{
Development of Listening Skills Materials Using Plotagon Story Application Multimedia
}

\author{
Kunti Nadiyah Salma ${ }^{1, *}$, Umi Machmudah ${ }^{2}$, Nurhidayati Nurhidayati ${ }^{3}$ \\ ${ }^{1}$ Sunan Giri Institute of Islamic Religion Ponorogo Indonesia \\ ${ }^{2}$ Maulana Malik Ibrahim State Islamic University Malang Indonesia \\ ${ }^{3}$ State University of Malang Indonesia \\ *Corresponding author.Email: Salma_KNS@insuriponorogo.ac.id,
}

\begin{abstract}
The purpose of this research are: 1) Describing how the process of developing multimedia listening skills by the plotagon story application for students of MAN Pacitan. (2) Describing what the characteristics of multimedia listening skills are by the plotagon story application for students of MAN Pacitan. (3) Describing how effectively using of multimedia listening skills by the plotagon story application for students of MAN Pacitan. The reason for choosing this title they are has not been found a suitable learning media for learning listening skills in 11 th grade senior high school and students there find it difficult to understand the lesson without the learning media. Researcher uses Research and Development ( R\&D ) research with Borg \& Gall method, which the stages are : problems - data collection - product design - product validation - product revision - product trial - product revision - field trial.
\end{abstract}

Keywords: Learning Materials, Multimedia, Plotagon Story Application, Listening Skills

\section{INTRODUCTION}

Learning Arabic has existed for a long time and always develops along with the times. As with other foreign language learning, learning Arabic also requires the teacher's ability in classroom management and also the ability to use learning media to facilitate the existing learning process and enliven the learning atmosphere in the classroom to make it more lively and interesting for students [1][Hamid, 2008]. From this it can be seen that a teacher is the main key in success in learning, so the teacher must be able to choose the right strategies and methods so that they can combine the existing material with the right learning media as well.

Now media is very concerned because it is in line with technological advances. Technology is now very advanced so that it can be used in various ways, especially in the world of education [2][العزيز, n.d.]. Currently, learning media has a very important role to achieve success in learning, whether it is the use of language laboratories, the internet, computers, etc [3] [Usman, 2002]. The development of tools and technology goes hand in hand and interrelated, learning media also experience developments that produce multimedia. Multimedia is one type of media that has several elements, namely: writing, images, sound, animation, and video [4] [Surjono, 2017]. According to Turban et al, multimedia is a tool to present knowledge in which there are more than 1 element. Multimedia also has the ability to present text, sound, images, moving animation, and video in one medium simultaneously so that it can attract the attention of people with various backgrounds [5][Oka, 2017].

It can be concluded that technology has now developed and advanced, so it can be used to transform education to assist and facilitate classroom teaching. So that teachers must be able to use them as teaching aids and good and excellent media in accordance with the subject matter and the student environment in it.

Arabic has four skill components, namely listening skills, speaking skills, reading skills, and writing skills. Listening skill is one of the skills that 
he wants to master in teaching foreign languages, including Arabic, and is the first and basic skill of the other three skills, because its role is very important [6][الخميس, n.d.]. Listening is a way for students to understand what they are learning and it has a high place in them. If students are not good listeners, they will not understand what the teacher is explaining. It is known that one of the teacher's tasks is to train students on an ongoing basis in understanding listening so that students can understand what they hear from sounds, decipher the symbols and understand them [7][الركابي, 1973].

Foreign language learners need to enter the language to increase their level of proficiency. Listening can give students the input they need. When listeners listen to listening texts especially for native speakers, their listening skills will improve and they will have better and better opportunities to use the language effectively [8][Naci, 2015]. Understanding listening is an important skill in all areas of academic life. Active listening of higher education students is necessary for formal understanding of lectures and tutorials, student interactions with others in small groups, project work, and social work [9][Picard, 2016].

The explanation above shows that listening skills are important and essential for other skills, because listening will lead to the ability to pronounce, read and write knowledge. And also a lot of people take the time to listen. The researcher found a problem in class XI at MAN Pacitan about teaching Arabic for listening skills. Based on the observation that listening material is in the form of conversational dialogues in textbooks. As for teaching listening skills by recording audio for class XI Arabic teachers, but not about the dialogue, such as for other subjects or by giving educational films.

The Arabic teacher for class XI MAN Pacitan said that he found it difficult to teach listening skills because there was no suitable media and he wanted to use video, but also there was no video that matched the material so he used recordings of his voice and sometimes films to educate students. student. Likewise, several students of class XI MAN Pacitan said that teaching listening skills reduced their interest because they always only heard sounds without pictures so it was not interesting so they had to imagine themselves about the conversations in the recording. And if they watch the movie, few of them understand about the dialogue in it because of its high language and fluency because the nathiq is original, fluent and fast.
Based on the explanation above and considering the importance of listening skills in learning Arabic, it encourages researchers to help students so that they can learn listening skills well, namely by developing listening skills material using the Plotagon Story application to be more effective in learning Arabic. Plotagon Story is software to help create good and correct animations as needed with ease of use, it is also possible to include audio into the animation so that the dialogue conveyed in the animation can be heard clearly [10] (Perancangan Film Animasi Pendek Plotagon Story, n.d.). The Plotagon Story application in another opinion is a type of software for creating content that is very easy to use and can be used in education because it is a form of textbased filmmaking, as a fictional story tool for making short films or feature films [11] [Guzmán Gámez \& Moreno Cuellar, 2019]. Another opinion of Plotagon Story is an application that allows students and teachers to create 3D animated videos simply by writing in scripts. The characters in the application speak the text written in English or if you want you can write in any language to record the voice of any language too [12] [Plotagon Story Education, n.d.].

The conclusion that can be drawn from these understandings is that Plotagon Story is an application or software to create animations with characters that we can choose as we wish and the output of this application is video. As for the material in it, only by writing text, the characters will speak in English, and if you want it in another language then by writing text and recording sound.

The software offers free trial options for individual story vendors, licensed versions for students and educators, and another for designers and professional users. According to Love, animated films must be produced from dialogue texts. Its uses in the classroom are practically endless. Students can use it to write short texts and then record audio so that it becomes a film as shown earlier. In addition, he can use it in a number of ways, including: creative writing, situation reporting (notes), and providing creative ways to add presentations. Next to it Love states that it is educationally valuable as it produces graphical output from text-based input, which is useful for classrooms and foreign language education [13] [Latif, Fauzi Syahputra, 2018].

\section{METHOD}

The approach used in this research is qualitative and quantitative. The researcher used a qualitative approach to describe the steps for developing 
listening skills using the Plotagon Story application for the students of MAN Pacitan. A quantitative approach is used to determine the effectiveness of the use of listening skills using the Plotagon Story application for MAN Pacitan students. The parent method used in this research is R\&D with the Borg \& Gall model. Development research is a research method used to obtain specific results and to test their effectiveness [14] [Gall, Meredith, n.d.].

According to Borg \& Gall, developmental research is the process used to develop and validate educational outcomes [15] (Setyosari, 2013). The steps for developing the Borg \& Gall model are: Problems, data collection, product design, product validation, product revisions, small-scale product trials, product revisions, and large-scale product trials [14] [Gall, Meredith, n.d.].

The population in this study were all students of class XI MAN Pacitan totaling 184 students. Because the population is very large or exceeds 100 , it is not possible for the object of research to take all of it so that it uses a sample, namely purposive sampling. As for the samples taken class XI IPS 1 MAN Pacitan as an experimental class, totaling 28 students and class XI IPS 2 as a control class, totaling 30 students.

While the tests given to students are pre-test and post-test with coverage of second semester Arabic listening skills

In this study, researchers used the following data analysis methods:

a. Qualitative analysis method to answer the first research question, which is related to how to develop listening skill material using the Plotagon Story application for MAN Pacitan students

b. Questionnaire to complete the answers to the first and second research questions and to obtain calculations using the Likert Scale type

c. T-test analysis method (independent t test)

$$
\frac{\mathrm{t}=\mathrm{M}_{\mathrm{x}}-\mathrm{M}_{\mathrm{y}}}{\mathrm{SE}_{\mathrm{Mx}}-\mathrm{My}}
$$

$\mathrm{M}_{\mathrm{x}} \quad$ : sample mean before using the application

$\mathrm{M}_{\mathrm{y}} \quad$ : sample average after using the application $\mathrm{SE}_{\mathrm{Mx}}-\mathrm{My}$ : standard error difference between $\mathrm{M}_{\mathrm{x}}$ and $\mathrm{M}_{\mathrm{y}}$

\section{RESULT AND DISCUSSION}

\subsection{Development of Listening Skills Materials Using Plotagon Story Application Multimedia}

\section{a. Problem}

The first step in this development is to find the problems that exist in the field. The problems found by the researchers here are problems in learning Arabic in class XI MAN Pacitan through interviews and observations. Researchers conducted interviews with Arabic teachers and several students of class XI.

From several points of questions posed to the Arabic language teacher in class XI MAN Pacitan, it can be seen that there are problems in learning Arabic related to listening skills material caused by learning media, namely Arabic language teachers have not found the right learning media and in accordance with the listening skills material. in textbooks. So far, the teacher uses the film even though it is less or not in accordance with the material in the textbook. Meanwhile, the Arabic language teacher in class XI really needs a learning media for listening skills according to the textbook. As for the results of interviews with several class XI students of MAN Pacitan, it was found that they had difficulty understanding the listening skills material in the textbook, because the films that were shown were not in accordance with the material in the textbook, especially in doing the exercises they felt very difficult. And also not infrequently the Arabic language used in films is a high language and is rarely used, so it is difficult for students to understand.

From the explanation above, it can be seen that there is a great need for the development of listening skills using multimedia plotagon story applications for students of MAN Pacitan. On the other hand, the researcher also made observations during Arabic learning that took place in class and the results of these observations, it can be concluded that the learning media used is very important and influential in learning listening skills on students' understanding.

\section{b. Collecting data}

Researchers collected data to analyze the need for developing listening skills using multimedia plotagon story applications for class XI students at MAN Pacitan through questionnaires distributed to class XI students at MAN Pacitan. The results of the questionnaire obtained are 2148 or $89.5 \%$, which is in a position of dire need, it proves that students really 
need the development of listening skills using multimedia plotagon story applications for class XI students of MAN Pacitan to help their understanding of the material.

\section{c. Product Design}

\section{1) Download the plotagon story app}

The first step that must be done is to download the plotagon story application on the play store.

2) Character design in the plotagon story app

After completing the download, the researcher designs the characters that will be used in the plotagon story application. Here, the researcher determines the gender of the character, the clothes used by the character, the character's hair, the shape of the character's face, shoes or sandals that the character will use, etc.

3) Conversation/video design in the plotagon story application

After the character has been created, the researcher begins to design a video or conversation in this application. Here the researcher designs the video to be made by determining the setting, character position, character conversation, and filling in the character's voice by recording it.

\section{d. Product Validation}

After finishing designing the product, the researcher validated the product to experts which included 3 experts, namely linguists, design experts, and material experts using a questionnaire so that the product was perfect and suitable for use. The experts are lecturers at the State Islamic University of Maulana Malik Ibrahim Malang who are in accordance with their respective fields.

The linguist validator here is Prof. Dr. Faisal Mahmud Adam. The results of the linguistics expert validation questionnaire were 36 or $90 \%$ who were at a very good level in terms of language, so this proves that the development of listening skills material using the plotagon story multimedia application is feasible to use in terms of language with several revisions to make it a better product and appropriate. The design expert validator in this reseach was Dr. HR Taufiqurrochman, MA. The results of the design expert validation questionnaire were 46 or $92 \%$ which were at a very good level in terms of design, so this proves that the development of listening skills material using the plotagon story multimedia application is feasible to use in terms of design without revision from the validator. The material expert validator in this research is Dr. H. Syaiful
Mushtofa, M. Pd. The results of the linguistics expert validation questionnaire were 47 or $94 \%$ who were at a very good level in terms of the material, so this proves that the development of listening skills material using the plotagon story multimedia application is feasible to use in terms of material with several revisions from the validator in order to become a better product.

\section{e. Product Revision}

The conclusion of the revision given by the validators lies in a language error, then the researcher makes a re-recording of the sound to revise the error.

\section{f. Product Trial}

After revising, the researcher conducted a product trial on a small group consisting of 12 students of class XI MAN Pacitan. After the product was given to the students, the researcher gave a satisfaction questionnaire to them to find out the students' shortcomings and opinions regarding the product. The results of the satisfaction questionnaire obtained from small groups of 459 or $95.6 \%$ which are at a very good level, this shows that the development of listening skills material using the plotagon story multimedia application is feasible for use in the classroom and students are very satisfied with it and feel very helped his understanding.

\section{g. Product Revision}

There is a slight revision here, which is only a change in the voice actor.

\section{h. Product Trial}

In this step the product is applied to the experimental class, namely class XI IPS 1 MAN Pacitan with 23 students. From the test results, it can be seen that there is an increase from the pre test to the post test, and in the post test scores, all students in class XI IPS 1 get scores above the KKM score, which is above 80. So this proves that learning Arabic is a listening skill material. in this class has succeeded and arrived at the goals to be achieved, and the use of the plotagon story application is very helpful for students' understanding of the material.

\subsection{Characteristics of Listening Skills Material Using Plotagon Story Application Multimedia}

a. Icon of plotagon story app

The special icon belonging to the plotagon story application is a camera image in the letter $\mathrm{P}$ which is a combination of pink orange and white. 


\section{b. Character}

In the plotagon story application, you can determine the character that will be used as desired. In it you can choose gender, determine clothes, pants, skirts, headscarves, sandals, shoes, skin color, head shape, etc.

c. Place

There are many choices for the background of the place, so you can choose according to your wishes, both free and paid.

\section{d. Voice}

For character voices in this plotagon story application, voice recordings are required if using Arabic. So in choosing voice actors, you should choose people who have a voice according to the required criteria and are fluent in Arabic so that the results are good and clear.

\section{e. Expressions/gestures}

Character expressions/movements can be selected from the available expression options in the plotagon story application.

\section{f. Interaction}

Interaction between characters can also be selected in the column that is already available in the plotagon story application.

\subsection{Effectiveness of Listening Skills Materials Using Plotagon Story Application Multimedia}

When the process of developing listening skills material using the plotagon story multimedia application for MAN Pacitan students is complete and all the steps are complete, the researcher conducts a trial. In this study, an experimental model was used so that it required a control class, namely class XI IPS 2 with 25 students. Researchers entered this class only 2 times for pre-test and post-test. Researchers used tests to measure students' ability in mastering listening skills before and after using plotagon story multimedia applications for the experimental class. Meanwhile, the control class was used to measure students' abilities before and after the teacher explained or provided listening skills. So at the end the researcher will compare the results in the experimental class with the control class.

Before doing the calculations, the researcher determines the research hypothesis, namely:
$\mathrm{H}_{0}=$ There is no effect of using the plotagon story application multimedia on the understanding of the listening skills of the XI MAN Pacitan students.

$\mathrm{H}_{\mathrm{a}}=$ There is an effect of using the plotagon story application multimedia on the understanding of the listening skills of the XI MAN Pacitan students.

The basis for making T-test decisions are as follows:

- If $\mathrm{T}$ count $>\mathrm{T}$ table $=\mathrm{H}_{0}$ is rejected and $\mathrm{Ha}$ is accepted

- $\quad$ If $\mathrm{T}$ count $<\mathrm{T}$ table $=\mathrm{H}_{0}$ is accepted and $\mathrm{Ha}$ is rejected

From the $t$ test which is calculated using spss, the results of the $\mathrm{t}$ test are 10.27400. Then From the results of the t-test above, it can be concluded that :

1. $\mathrm{T}$ table is 0.67986 , because $\mathrm{df}=46$ with an error percentage of $5 \%$

2. $\mathrm{T}$ count $>\mathrm{T}$ table $=10.27400>0.67986$ then $\mathrm{H}_{0}$ is rejected and $\mathrm{H}_{\mathrm{a}}$ is accepted. So it is clear that there is an effect of using the plotagon story application multimedia on the understanding of the listening skills material for class XI MAN Pacitan students.

\section{CONCLUSION}

The conclusion of this research are: (1) The process of developing multimedia listening skills by the plotagon story application which the following stages : Problems (problems known by interviews and observations), Data collection (after knowing the problems then collecting data for needs analysis by a questionnaire), Product Design (including procedures for downloading applications plotagon story, procedures for making characters, and design for making multimedia listening skills by the application of plotagon story), Product Validation (includes validation of linguists, material experts, and design experts), Product Revision, Product Trial (for small groups of 12 students), Product Revision, Field trials (applied in the experimental class that is class XI IPS 1 with pre-test and post-test). (2) Multimedia characteristics of listening skills by the plotagon story application include the plotagon story application icon, characters, place settings, sounds, movements, and character interactions. (3) The effectiveness of multimedia listening skills by the plotagon story application is proven to support students in understanding the material of listening skills in textbooks based on: the results of the $t$ test are $t$ count $>\mathrm{t}$ table $=10.27400>0.67986$, then $\mathrm{H}_{\mathrm{o}}$ is rejected 
and $\mathrm{H}_{\mathrm{a}}$ is accepted then there is an influence of the use plotagon story application to support student's understanding of the material on listening skills in learning Arabic and using the multimedia application is effective.

\section{REFERENCES}

[1] A. Hamid, Pembelajaran Bahasa Arab Pendekatan, Metodem Strategi, Materim dan Media. UIN Maliki Press, 2008

[2] Al Aziz. Syin.ain, Allughoh Al Arabiya wal Fikru Al mustaqbali.darul jayyid

[3] B. Usman, Media Pembelajaran. Ciputat Pers, 2002

[4] H. D. Surjono, Multimedia Pembelajaran Interaktif. UNY Press, 2017

[5] G. P. A. Oka, Media dan Multimedia Pembelajaran. Deepublish, 2017

[6] F. istima', alkhomis,ain, Alif,ba',shod

[7] J. Arrokabi, turuqu tadrisul lughoh alarabiyah. Darul Fikri, 1973

[8] Y. Naci, \& M. A., "The Role of Listening Skills in Developing Communicative Competence: A Case Study in the Language Classroom". International Journal of Social Sciences \& Educational Studies, 2(5) (2015)
[9] M. Picard, \& L. V. "Developing Independent Listening Skill for English as an Additional Language Students, University of Adelaide". International Journal of Teaching in Higher Education, 28(1) (2016).

[10] Perancangan Film Animasi Pendek Plotagon Story. (n.d.). https://digilib.uns.ac.id/...=/Perancangan-filmanimasi-pendek-Ardawalika-abstrak.pdf

[11] D. Y. G. Gámez, D. Y., \& J. A. M. Cuellar. The use of plotagon to enhance the english writing skill in secondary school students. Profile: Issues in Teachers' Professional Development, 21(1) (2019), 139-153. https://doi.org/10.15446/profile.v21n1.71721.

[12] Plotagon Story education. (n.d.). https://plotagon.com/education

[13] F. S. Latif, Membuat Animasi dengan Aplikasi Plotagon Story, 2018

[14] Gall, Meredith, Educational Research Seventh Edition. Pearson Education.

[15] P. Setyosari, Metode Penelitian Pendidikan dan Pengembangan. Prenadamedia Group, 2013. 